\begin{tabular}{l|c|l}
\hline \hline Biological and & Vol. 6(1): 58-67, 2022 & $\begin{array}{l}\text { ISSN: 2002-6153 } \\
\text { Biol. Appl. Environ. Res. } \\
\text { www.baerj.com } \\
\text { editor@a baerj.com }\end{array}$ \\
\hline
\end{tabular}

\title{
Determining Role of TGF- $\beta 3$ in Some Treatments of Albino Mouse, Mus musculus Linnaeus, 1758 Infected with Hydatid Cyst by Using an Immunohistoflourescent Staining Technique
}

\author{
Afrah A. Sadek \\ Al-Karkh III Baghdad Education Directorate, Baghdad, Iraq \\ *Corresponding author: ah300596@gmail.com
}

\begin{abstract}
The present study was conducted as an attempt to treat secondary hydatid disease in white mice strain Balb/c by immunohistoflourescent (IHF) staining technique. For this purpose, the mice were infected with hydatid cysts and treatment was done by oxfendazole (OFZ) at a concentration of $30 \mathrm{mg} / \mathrm{kg}$, praziquantel (PZQ) at a concentration of $40 \mathrm{mg} / \mathrm{kg}$ and albendazole (ABZ) at a concentration of $10 \mathrm{mg} / \mathrm{kg}$ of body weight. Each drug was given weekly for four months and the same concentrations as above. The results showed that the highest treatment efficiency was in case of OFZ + PZQ treated mice, while the groups treated with $\mathrm{OFZ}, \mathrm{OFZ}+\mathrm{ABZ}$ and $\mathrm{ABZ}+\mathrm{PZQ}$ showed less treatment efficiency, respectively. The IHF staining technique was used to determine the cytokinesis of TGF- $\beta 3$ in the spleen and liver of experimental mice. For this reason, OFZ is considered as one of the most promising chemotherapies used in the treatment of hydatid cysts.
\end{abstract}

Keywords: Immunohistoflourescent, TGF- $\beta 3$, Mus musculus, Echinococcus granulosus, Oxfendazole

\section{Introduction}

Hydatid disease is a common disease between humans and animals. The causative agent of the disease is the larval stage (metacestode) of the tapeworm of the genus Echinococcus (Wahlers et al., 2012). The host's resistance to the parasite Echinococcus granulosus depends on the cellular immunity of the Th1 helper T cells, while the susceptibility to infection depends on the secretions of the helper T cells Th 2 (Zhang et al., 2003), called cytokines, which are important in regulating the immune response in all stages of the immune response in addition to its effect on innate and acquired immunity. Transforming growth factor- $\beta 3$ (TGF- $\beta 3$ ) protein is a regulatory cytokine, which is secreted from lymphocytes, phagocytes and dendritic cells, and works on the growth, proliferation, differentiation of cells, programmed cell apoptosis (Vaughn et al., 2000). It plays their role in controlling the immune system, and is one of the great regulators in the immune response, stimulates and regulates organized $\mathrm{T}$ cells. It reduces toxic factors in the immune response and chronic inflammatory diseases and induces fibrosis in many worm infestations (Harraga et al., 2003). 
In view of the absence of previous studies conducted in Iraq, on the use of a drug from the benzimidazole derivatives (oxfendazole), and its use alone or mixed with another drugs, such as albendazole and praziquantel, which are the most commonly used to treat hydatid cysts, hence, prospects are opened in trying to treat this disease both immunologically and chemically. The members of the experimental mice were tested in this study by using the IHF staining technique to determine the expression of TGF- $\beta 3$ in spleen and liver of experimental mice.

\section{Material and Methods}

\section{Experimental Animals}

Ninety Balb/C strain white male mice (Mus musculus Linnaeus, 1758), 4-5 weeks old, weighing $20 \pm 5 \mathrm{~g}$, obtained from the Drug Control Department in Baghdad were used. These mice were transferred directly to the animal house of the study site for breeding under the appropriate environmental conditions.

\section{Preparation of Hydatid Fluid Antigen and Protoscolices}

Hydatid cyst samples were collected from local sheep whose livers were naturally infected with cystic echinococcosis after slaughtering in the Al-Shula slaughterhouse in Baghdad. Smyth \& Barrett (1980) method was used to extract hydatid cyst fluid antigen (HCFAg) at a concentration of $3.36 \mathrm{mg} / \mathrm{ml}$ by using Bradford (1976) method. Approximately 2,000 live protoscolices per mouse were injected in a single dose (Wangoo et al., 1989).

\section{Mice Injection}

Mice were injected at a challenge dose of $2000 \pm 5$ protoscolices in intra peritoneal cavity (I/P) needle after sterilization of the injection area with $70 \%$ ethyl alcohol, at the same time. The positive control group (15 mice) was injected with the same dose of the protoscolices, while the negative control group (15 mice) was injected with $0.2 \mathrm{ml} /$ mouse of the physiological buffer saline (PBS).

\section{Preparation of the Drugs}

Three drugs had been used in an attempt to treat secondary hydatid cysts in mice that were experimentally infected with protoscolices in the intraperitoneal cavity. The drugs were:-

1- Albendazole (ABZ) at a concentration of $10 \mathrm{mg} / \mathrm{kg}$ of body weight, equivalent to $0.01 \mathrm{mg} / \mathrm{kg}$ human equivalent dose (HED) according to Pérez-Molina et al. (2011).

2- Oxfendazole (OFZ) at a concentration of $30 \mathrm{mg} / \mathrm{kg}$ of body weight, equivalent to $0.04 \mathrm{mg} / \mathrm{ml}$ (Gavidia et al., 2010).

3- Praziquantel (PZQ) at a concentration of $40 \mathrm{mg} / \mathrm{kg}$ of body weight, equivalent to $0.06 \mathrm{mg} / \mathrm{ml}$ (Gavidia et al., 2010).

The drugs given to groups of mice were divided individually or in combination with the same concentrations as above.

1- OFZ, 2- OFZ+PZQ, 3 -OFZ+ABZ, 4- ABZ+PZQ 
OFZ was used at a concentration of $30 \mathrm{mg} / \mathrm{kg}$ of body weight, equivalent to 0.5 $\mathrm{mg} / \mathrm{ml}$ (Gavidia, et al., 2010) and the drug was locally obtained (Synanthic ${ }^{\circledR}$, Fort, Dodge, Mexico).

Groups of rats were dosed one week after a challenge dose of $0.25 \mathrm{ml}$ of OFZ oral administration, as one dose per week for four months. The negative control group was dosed with the same volume of distilled water. Four months after giving the challenge dose, the mice were killed and the internal organs were examined.

\section{Histopathological Examination}

Preparation, examination and photographing those sections was done by using a compound microscope, Olympus type, equipped with a Konica type camera, and using Konica films with a sensitivity of 100 ASA.

\section{Immunohistoflourescent Examination}

The immunohistochemical tests for tissue staining work, where specific antibodies conjugated to fluorecenisothiocyanate (FITC) staining technique were used to examine the immunological activity of those antibodies by using histological growth factor (TGF- $\beta 3$ ) according to the manufacturer's instructions (the DAKO Envision Detection Kit K5007) as follows:-

1- After obtaining tissue slices of the liver and spleen of the study group, with a thickness of 4-5 micrometers, by means of a rotary microtome device, the cut strips were carried out by using a small brush on charged slides.

2 - The slices were placed in the oven for 30 minutes, then placed in the xylene in the oven at a temperature of $60^{\circ} \mathrm{C}$ for 10 minutes.

3- The slides were taken out of the oven and placed in xylene for two stages, each stage, for five minutes, to get rid of the wax, for five minutes for two rounds.

4- The slides were dried and outlined with a pap pen by drawing a circle around the tissue section.

5- The slides were placed in a humid chamber and peroxidase was added. Peroxidase reagent was in the form of drops that cover the slide for 15 minutes at room temperature.

6- The slides were washed with buffer PBS $=7.4$ for five minutes and then dried.

7- The slides were returned to the wet jar, and $50 \mu$ of protein block or bovine serum albumin were added to each histological section to block antibody determinants (proteins).

8- The slides were washed with buffer PBS $=7.4$ for five minutes and then dried.

9- The slides were returned to the wet jar and the primary antibody (growthconverting factor) TGF- $\beta 3$ was applied in a 50:1 dilution ratio with protein block solution. The neighbor was placed in the incubator, and incubated at $37^{\circ} \mathrm{C}$ for one hour or for the next day, overnight.

10- The slides were washed with buffer PBS $=7.4$ for five minutes and then dried.

11- The slides were placed in the jar. Conjugate fluorescent rabbit serum was added in the form of drops covering the tissue sections. Then, they were placed in the incubator at $37{ }^{\circ} \mathrm{C}$ for one hour. 
12- The tissue sections were washed with buffer PBS $=7.4$ solution for five minutes, then they were placed in distilled water for five minutes.

13- The tissue sections were passed a series of dehydration alcohols with a concentration of $50 \%, 60 \%, 70 \%, 80 \%, 90 \%$ and $100 \%$ for five minutes for each concentration and then transferred to xylene in two stages for five minutes in each stage for the purpose of clearing.

14- A drop or two DPX mounting medium was tightened, the cover slip was placed and left to dry.

15- The slides were examined under an Olympus fluorescence microscope equipped with a camera.

\section{Results}

\section{Immunohistofluorescence of Liver and Spleen}

\section{Transforming Growth Factor $\beta-3$}

The results of histological immunostaining with FITC method showed that the spleens of the experimental mice (Plates $1,4,5,8$ ), treated lymphocytes stained with a bright green color for TGF- $\beta 3$ expression, and the cytoplasm of hepatocytes was colored in bright green by FITC method (Plates 2, 3, 6, 7).

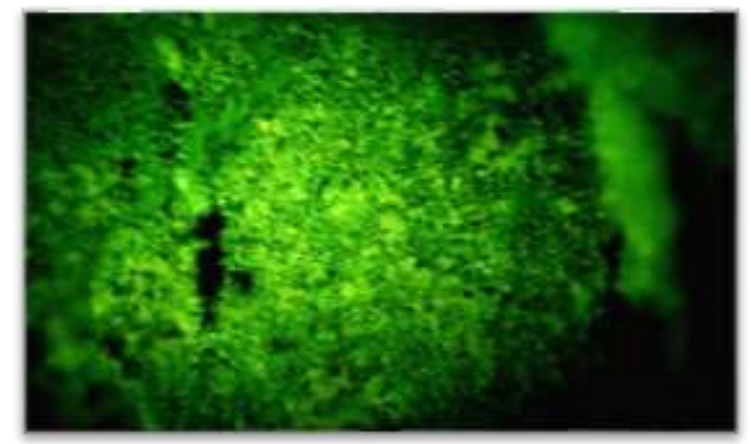

Plate 1: Section of the spleen of OFZ-treated mice showing the expression of TGF- $\beta 3$ in FITC-mediated bright green stained lymphocytes (40X).

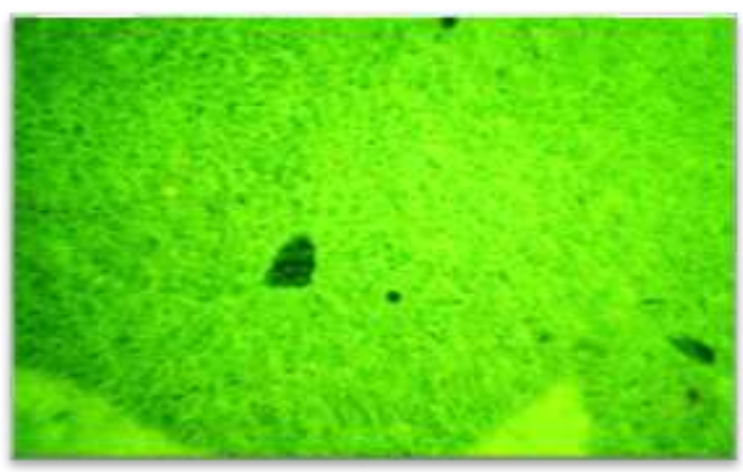

Plate 2: Section of the liver of OFZ-treated mice showing the expression of TGF- $\beta 3$ protein in bright green pigmented lymphocytes and hepatic cytoplasm with bright green color by FITC method (40X). 


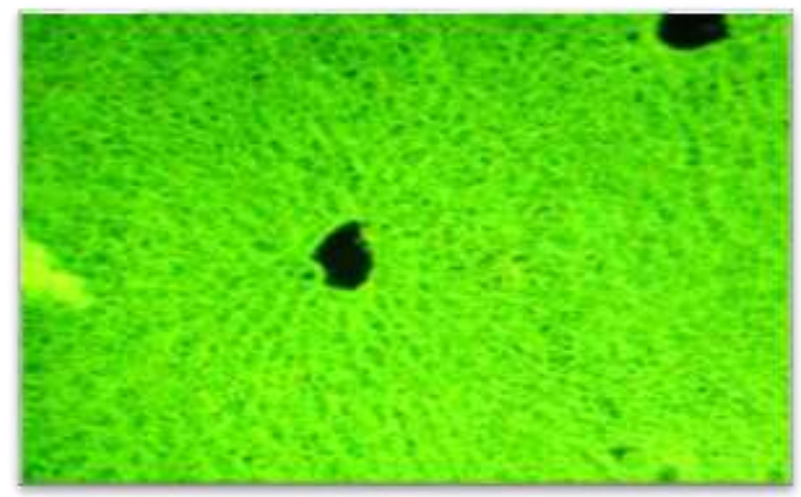

Plate 3: Section of the liver of OFZ+PZQ treated mice showing expression of TGF- $\beta 3$ in bright green pigmented lymphocytes and bright green hepatocytes diffuse in the cytoplasm liver by FITC method (40X).

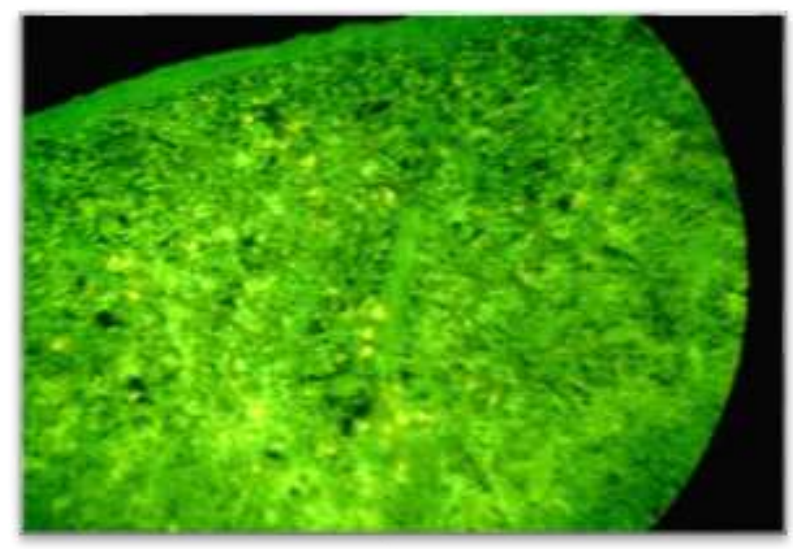

Plate 4: Section of the spleen of OFZ+PZQ treated mice showing the expression of TGF- $\beta 3$ in bright green pigmented lymphocytes by FITC method (40X).

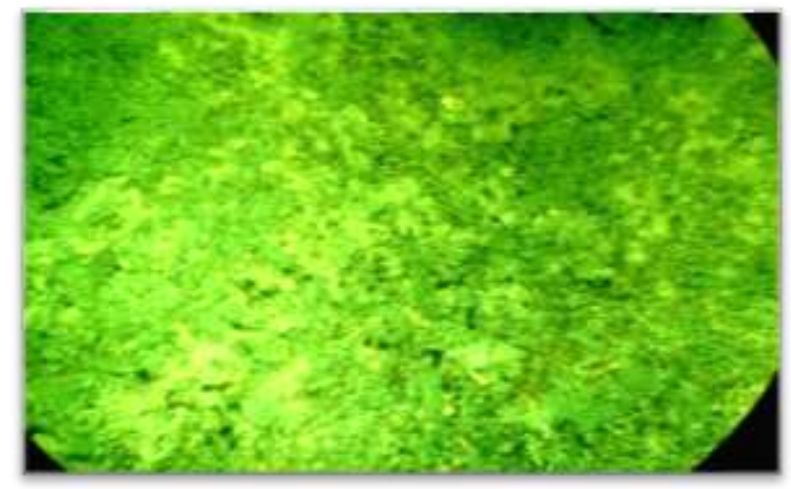

Plate 5: Section of the spleen of OFZ+ABZ treated mice showing the expression of TGF$\beta 3$ in bright green colored lymphocytes by FITC method (40X). 


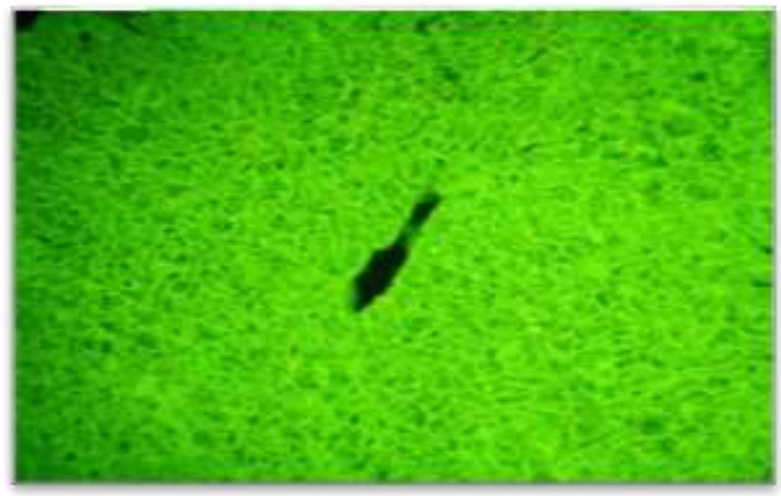

Plate 6: Section of the liver of $\mathrm{OFZ}+\mathrm{ABZ}$ treated mice showing the expression of TGF- $\beta 3$ (IHC) in lymphocytes stained in bright green and the cytoplasm of hepatocytes in bright green $(40 \mathrm{X})$.

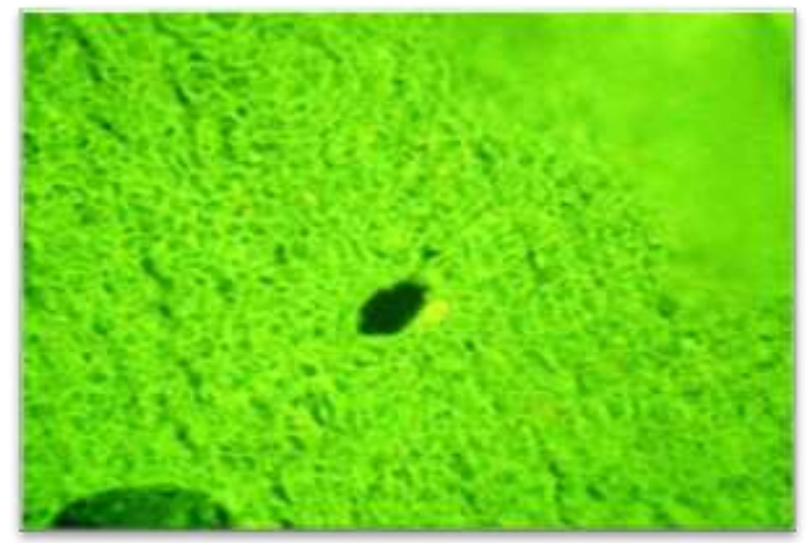

Plate 7: Section of the liver of mice treated with ABZ + PZQ showing the expression of TGF- $\beta 3$ in bright green pigmented lymphocytes and bright green hepatocytes diffused in the cytoplasm liver by FITC method (40X).

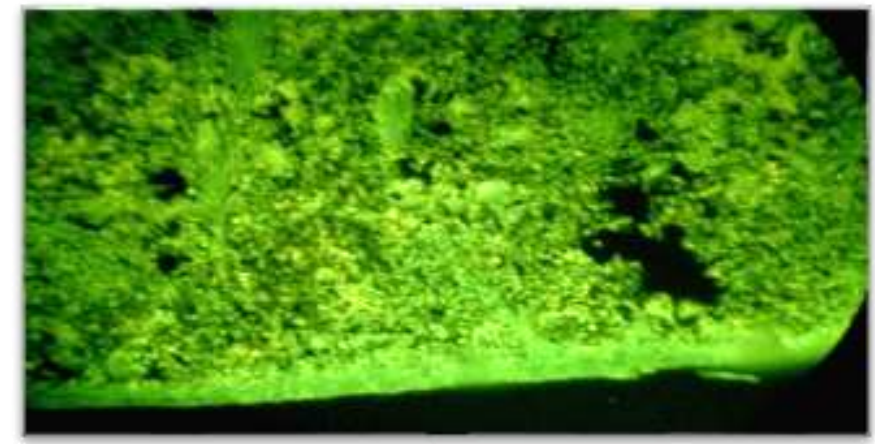

Plate 8: Section of the spleen of mice treated with ABZ+PZQ showing the expression of TGF- $\beta 3$ lymphocytes stained with green color by FITC method (40X). 


\section{Discussion}

In the current study, a clear expression of TGF- $\beta$ was observed in the red pulp of the spleen, while moderate expression in the white pulp. This result is consistent with Ueda et al. (2003). The predominantly pigmented cells are macrophages and lymphocytes. In the liver, the expression was more pronounced in hepatocytes along the central vein. Significant differences appeared between the treated groups in IFAT in the tissue sections of the liver and spleen, and most of the pigmented cells appeared in a bright green color. On the production of cytokines, it is possible that it activates white blood cells and endothelial cells, and stimulates them to secrete cytokines. This is consistent with what was found by Reuben et al. (1979) upon activation of chelating macrophages by tuberculosis vaccine, which reversed an increase in lymphocyte counts and colony stimulating factor (CSF) secretion. TGF- $\beta$ is a multifunctional cytokine that either stimulates or inhibits cell proliferation depending on cell type, the differentiating state of the cells and the environment in which they operate (Barnard et al., 1990). The role of TGF- $\beta$ in liver regeneration remains an enigma. TGF plays a pivotal role in hepatocyte regeneration (Fausto et al., 1991). The liver is a place for different types of cells of hepatic, biliary and visceral origin, and during the regeneration of hepatocytes, all of these cells restore the size of the liver by coordinating action with the kinetic TGF- $\beta$. It seems that TGF- $\beta$ produces the ground for new divisions of the hepatocytes by means of the consolidation and reconstruction of the extracellular matrix and thus somewhat inhibits the growth of unnecessary hepatocytes. Martinez-Hernandez \& Amenta (1995) and Uyama et al. (2002) worked to stop the building of DNA in hepatocytes. Mutations in TGF- $\beta 3$ cause many diseases, including chest diseases and osteoporosis (Rienhoff et al., 2013; Matyas et al., 2014; Bertoli-Avella et al., 2015). Normal hepatocytes are unable to activate latent TGF, but regeneration-inducing hepatocytes have such a capacity (Jakowlew et al., 1991). TGF appears to be a negative regulator of hepatocyte proliferation and in this way determines liver size and several immunosuppressive cytokines (Huang et al., 2013). Immunosuppressive expression TGF- $\beta$ is observed in most parts of granulomatous lesions, inflammatory areas in the liver and visceral tissues, especially these areas near damaged cystic Echinococcus (CE). Increased expression of TGF- $\beta$ is observed in the epithelial cells of liver sinusoids and fibroblasts. Recent studies have indicated that visceral cells including the epithelial cells of the liver are the main source of TGF- $\beta$. Thus, they work by inhibiting the growth factors on the liver cells by lateral effect "paracrine" (Nakatsukasa et al., 1990; Jakowlew et al., 1991; Fausto et al., 1995).

According to Ueda et al. (2003), TGF- $\beta 1$ is formed in the spleen and secreted into the portal bloodstream. Expression of TGF- $\beta$ in the spleen coincides with plasma concentrations of TGF- $\beta$. Other organs, such as the pancreas or stomach are sources of TGF- $\beta 1$ in the portal circulation. The release of TGF from these organs has a similar effect on hepatocytes, which is the anti-proliferation effect (Kahn et al., 1990). The mechanism of increased build-up of TGF- $\beta$ in the spleen during liver regeneration is not yet clear (Lin et al., 2011). It means that $E$. 
multilocularis posteriorly exerts a profound influence on liver homeostasis by modulating a number of gene expression and metabolic pathways, and that tissue damage stimulates the production of cytokines (Falk et al., 2005). Immunity of mice injected with protozoans stimulates both Th2 and Th1 (Al-Qaoud \& AbdelHafez, 2005).

Th2 cytokines were concentrated in the serum of patients with hydatid cysts as the parasite continued to grow in the body. Zhang et al. (2003) reported that tissue damage and programmed cell death stimulate the production of cytokines that mediate the effect of drugs and reduce their negative effects.

\section{References}

Al-Qaoud, K.M. \& Abdel-Hafez, S.K. (2005). Humoral and cytokine responses during protection of mice against secondary hydatidosis caused by Echinococcus granulosus. Parasitol. Res., 98: 54-60. DOI:10.1007/s00436005-0004-z.

Barnard, J.A.; Lyons, R.M. \& Moses, H.L. (1990). The cell biology of transforming growth factor beta. Biochim. Biophys. Acta, 1032(1): 79-87. DOI:10.1016/ 0304-419x(90)90013-q. PMID: 2194569.

Bertoli-Avella, A.M.; Gillis, E.; Morisaki, H.; Verhagen, J.M.A.; de Graaf, B.M.; Van de Beek, G.; Gallo, E.; Kruithof, B.P.T.; Venselaar, H.; Myers, L.A.; Laga, S.; Doyle, A.J.; Oswald, G.; van Cappellen, G.W.A.; Yamanaka, I.; van der Helm, R.M.; Beverloo, B.; de Klein, A.; Pardo, L.; Lammens, M.; Evers, C.; Devriendt, K.; Dumoulein, M.; Timmermans, J.; Bruggenwirth, H.T.; Verheijen, F.; Rodrigus, I.; Baynam, G.; Kempers, M.; Saenen, J.; Van Craenenbroeck, E.M.; Minatoya, K.; Matsukawa, R.; Tsukube, T.; Kubo, N.; Hofstra, R.; Goumans, M.J.; Bekkers, J.A.; Roos-Hesselink, J.W.; van de Laar, I.M.B.H.; Dietz, H.C.; Van Laer, L.; Morisaki, T.; Wessels, M.W. \& Loeys, B.L. (2015). Mutations in a TGF- $\beta$ ligand, TGF $\beta 3$, cause syndromic aortic aneurysms and dissections. J. Am. Coll. Cardiol., 65(13): 1324-1336. DOI:10.1016/j.jacc.2015.01.040.

Bradford, M.W. (1976). A rapid and sensitive method for the quantitation of microgram quantities of protein utilizing the principle of protein-dye binding. Anal. Biochem., 72: 248-254. DOI:10.1006/abio.1976.9999.

Falk, R.; Hacham, M.; Nyska, A.; Foley, J.F.; Domb, A.J. \& Polacheck, I. (2005). Induction of interleukin-1 $\beta$, tumor necrosis factor- $\alpha$ and apoptosis in mouse organs by amphotericin $\mathrm{B}$ is neutralized by conjugation with arabinogalactan. J. Antimicrob. Chemother., 55(5): 713-720. DOI:10.1093/ jac/dki090.

Fausto, N.; Laird, A.D. \& Webber, E.M. (1995). Liver regeneration. 2: Role of growth factors and cytokines in hepatic regeneration. FASEB J., 9(15): 15271536. DOI:10.1096/fasebj.9.15.8529831.

Fausto, N.; Mead, J.E.; Gruppuso, P.A.; Castilla, A. \& Jakowlew, S.B. (1991). Effects of TGF-beta $\mathrm{s}$ in the liver: Cell proliferation and fibrogenesis. Ciba Found. Symp., 157: 165-174. DOI:10.1002/9780470514061.ch11. 
Gavidia, C.M.; Gonzales, A.E.; Barron, E.A.; Ninaquispe, B.; Llamosas, M.; Verastegui, M.R.; Robinson, C. \& Gilman, R.H. (2010). Evaluation of oxfendazole, praziquantel and albendazole against cystic echinococcosis: A randomized clinical trial in naturally infected sheep. Plos Negl. Trop. Dis., 4(2): e616. DOI:10.1371/journal.pntd.0000616.

Harraga, S.; Godot, V.; Bresson-Hadni, S.; Mantion, G. \& Vuitton, D.A. (2003). Profile of cytokine production within the periparasitic granuloma in human alveolar echinococcosis. Acta Trop., 85(2): 231-236. DOI:10.1016/s0001706x(02)00218-8.

Huang, X.; Zou, Y.; Lian, L.; Wu, X.; He, X.; Wu, X.; Huang, Y. \& Lan, P. (2013). Changes of $\mathrm{T}$ cells and cytokines TGF-B1 and IL-10 in mice during liver metastasis of colon carcinoma: Implications for liver anti-tumor immunity. J. Gastrointest. Surg., 17: 1283-1291. DOI:10.1007/s11605-013-2194-5.

Jakowlew, S.B.; Mead, J.E.; Danielpour, D.; Wu. J.; Roberts, A.B. \& Fausto, N. (1991). Transforming growth factor-beta (TGF-beta) isoforms in rat liver regeneration: Messenger RNA expression and activation of latent TGF-beta. Cell Regul., 2(7): 535-548. DOI:10.1091/mbc.2.7.535.

Kahn, D.; Von Sommoggy, S.; Hickman, R. \& Terblanche, J. (1990). Ileocolectomy enhances the regenerative response after partial hepatectomy in the pig. S. Afr. J. Surg., 28(1): 11-13. PMID: 2339296.

Lin, R.; Lü, G.; Wang, J.; Zhang, C.; Xie, W.; Lu, X.; Maantion, G.; Martin, H.; Richert, L.; Vuitton, D.A. \& Wen, H. (2011). Time course of gene expression profiling in the liver of experimental mice infected with Echinococcus multilocularis. Plos One, 6(1): e14557. DOI:10.1371/ journal.pone.0014557.

Martinez-Hernandez, A. \& Amenta, P.S. (1995). The extracellular matrix in hepatic regeneration. FASEB J., 9: 1401-1410.

Matyas, G.; Naef, P.; Tollens, M. \& Oexle, K. (2014). De novo mutation of the latency-associated peptide domain of TGF- $\beta 3$ in a patient with overgrowth and Loeys-Dietz syndrome features. Am. J. Med. Genet., 164A(8): 21412143. DOI:10.1002/ajmg.a.36593.

Nakatsukasa, H.; Evarts, R.P.; Hsia, C.C. \& Thorgeirsson, S.S. (1990). Transforming growth factor-beta 1 and type 1 procollagen transcripts during regeneration and early fibrosis of rat liver. Lab. Invest.: J. Tech. Method Pathol., 63(2): 171-180. PMID: 2381163.

Pérez-Molina, J.; Díaz-Menendoz, M.; Gallego, J.I.; Norman, F.; Monge-Maillo, B.; Avala, A.P. \& López-Vélez, R. (2011). Evaluation of nitazoxanide for the treatment of disseminated cystic echinococcosis: Report of five cases and literature review. Am. J. Trop. Med. Hyg., 84(2): 351-356. DOI:10.4269/ ajtmh.2011.10-0513.

Reuben, J.M.; Tanner, C.E. \& Portelance, V. (1979). Protection of cotton rats against experimental Echinococcus multilocularis infections with BCG cell walls. Infect. Immun., 23(3): 582-586.

Rienhoff, H.Y.Jr.; Yeo, C.-Y.; Morissette, R.; Khrebtukova, I.; Melnick, J.; Luo, S.; Leng, N.; Kim, Y.-J.; Schroth, G.; Westwick, J.; Vogel, H.; McDonnell, N.; 
Hall, J.G. \& Whitman, M. (2013). A mutation in TGF- $\beta 3$ associated with a syndrome of low muscle mass, growth retardation, distal arthrogryposis and clinical features overlapping with Marfan and Loeys-Dietz syndrome. Am. J. Med. Genet., 161A(8): 2040-2046. DOI:10.1002/ajmg.a.36056.

Smyth, J.D. \& Barrett, N.J. (1980). Procedures for testing the viability of human hydatid cysts following surgical removal, especially after chemotherapy. Trans. Roy. Soc. Trop. Med. Hyg., 74(5): 649-652. DOI:10.1016/00359203(80)90157-1.

Ueda, S.; Yamanoi, A.; Hishikawa, Y.; Dhar, D.K.; Tachibana, M. \& Nagasue, N. (2003). Transforming growth factor-1 released from the spleen exerts a growth inhibitory effect on liver regeneration in rats. Lab. Invest., 83: 15951603. DOI:10.1097/01.LAB.0000095686.10639.C8.

Uyama, N.; Shimahara, Y.; Kawada, N.; Seki, S.; Okuyama, H.; Iimuro, Y. \& Yamaoka, Y. (2002). Regulation of cultured rat hepatocyte proliferation by stellate cells. J. Hepatol., 36(5): 590-599. DOI:10.1016/s01688278(02)00023-5.

Vaughn, S.P.; Broussard, S.; Hall, C.R.; Scott, A.; Blanton, S.H.; Milunsky, J.M. \& Hecht, J.T. (2000). Confirmation of the mapping of the Camurati-Englemann locus to 19q13. 2 and refinement to a 3.2cM region. Genomics, 66(1): 119121. DOI:10.1006/geno.2000.6192.

Wahlers, K.; Menezes, C.N.; Wong, M.L.; Zeyhle, E.; Ahmed, M.E.; Ocaido, M.; Stijnis, C.; Romig, T.; Kern, P. \& Grobusch, M.P. (2012). Cystic echinococcosis in sub-Saharan Africa. Lancet Infect. Dis., 12(11): 871-880. DOI:10.1016/S1473-3099(12)70155-X.

Wangoo, A.; Ganguly, N.K. \& Mahajan, R.C. (1989). Phagocytic function of monocytes in murine model of Echinococcus granulosus of human origin. Indian J. Med. Res., 89: 40-42. PMID: 2914730.

Zhang, W.; Li, J. \& McManus, D.P. (2003). Concepts in immunology and diagnosis of hydatid disease. Clin. Microbiol. Rev., 16(1): 18-36. DOI:10.1128/ CMR.16.1.18-36.2003. 